\title{
The Historical Gaps and Political Development Problems of Iran
}

\author{
Seyed Shamseddin Sadeghi ${ }^{1}$ \\ ${ }^{1}$ Department of Politics, Faculty of Social Sciences, Razi University, Kermanshah, Iran \\ Correspondence: Seyed Shamseddin Sadeghi, Department of Politics, Faculty of Social Sciences, Razi \\ University, Kermanshah, Iran. E-mail: sh.sadeghi@razi.ac.ir
}

Received: December 2, 2016

doi:10.5539/jpl.v10n2p276
Accepted: February 19, 2017 Online Published: February 28, 2017

URL: https://doi.org/10.5539/jpl.v10n2p276

\begin{abstract}
The analysis of the impediments to political development is one of the most important discussions which have major theoretical and political consequences. We cannot deny that fact that the forces influenced Historical Gaps can influence the Political Development of Iran. If we observed the process Political Development of Iran and the history of Iran we will find that it they have been evolving independently but still the changes in the environment of Iran have influenced them in addition to other things. These researches include the publications related to social and cultural history of the said period. In this paper we will initially identify the motivated ideologically and the state driven historiography trends. After that we will discussed it in contrast with the current evolution of historical studies of the period that is related to post-revolutionary Iran. In this study, takes Historical Gaps, a key element in this discussion, and explains the major Historical Gaps to political development in Iran.This paper focuses on the historical attitudes of people towards the political management of the society and the effect these attitudes have on slowing the development of this political system in the society. Historical Gaps will be extremely interested in this provocative text.
\end{abstract}

Keywords: Iran, historical gaps, political culture, political development

\section{Introduction}

Political development means institutionalize the political life. Without powerful political entities, society is lack of necessary mechanisms for determine and vindicate the public interests. Because of this we aim to study the relational explanation between Historical Gaps and Political development of Iran. In this paper, Historical Gaps are treated as one of the important agents and obstacles for Iran Political development and their effects will be specified on the country cultural, political and social structures. In this research, Historical Gaps means to express the gaps that are created by the invasion and attack of ranger aggressive nations on this country history, culture and identity figure and they are changed the historical and civilization evolutionary route of this land residents to get desirable development levels. Therefore, in this research we use an analytical-historical approach to analysis it and we try to find a suitable answer to the present question: what are the effects of Historical Gaps on Iran Political development process? In order to this we test the present hypothesis "Iran Political development is blocked by Historical Gaps".

\section{Discussion Framework}

Graham E. Fuller in his work "The Center of the Universe: The Geopolitics of Iran", claims: when the culture of a foreign enemy and foreign military forces impose on a nation, some replacements and shifts occur in local political culture and its authority hierarchy. Thus, the conspiracy mentality especially in international policy area becomes one of the political culture displays. Iranians are so sensitive to the role of foreigners in their culture and policy. This attitude, causes to create pessimism moral about the nature of political power among them" (Fuller, 23-26:1995).

Most of the foreign observers that are travelled to Iran or the researchers who have studied and researched about Iran problems, believe that the main features of Iran policy are distrust, insecurity and faction. Lord Curzon in his book Persia and Persian question concludes that: "Iranian are distrustful and suspicious people that they tend to see a conspiracy under each lining" (Curzon, 2012). Professor A. Lambton in his work: Islamic Society in Iran, reminds that faction in different ways are the main features of Iranian life from past until present (Abrahamian, Ashraf, Katouzian, 2008: 40). Sadegh Zibakalam in his work Conspiracy Figment claims that: "A territory that its north was invaded by Russia army and its south by Englishmen and its west was occupied by Ottoman; a land 
that foreigners constantly interfered with its affairs; this society believes a superhuman power, gently. The fact is that Britain authority in Iran, was a landmark in Iran history and also the Russia authority; unfortunately, America authority thereafter; thus we have such a history memory than foreigners interfere with our affairs and these factors are very effective to happen the conspiracy theory and its role in Iran backwardness"(Zibakalam, 2000, 29-30).

Why this happened exactly? In this part we study the territorial situation of Iran and foreigner aggressive nations invasion and their external attacks during the last history of this country and also the foreigners dominate authorities interfere in Iran affairs, how the country political management was disturbed and the way of Iran Political Development was roughed and its realization became an image.

\section{Historical Gaps}

Having a Geographical situation and Political-economic circumstances, Iran as an universal intersection, on one hand was a center of various cultures and civilizations and on the other hand, was attacked by different tribes and nations. These attacks destroying the irrigation systems and agriculture installation, Collapse the economic relations and social system binding, spread genocide and destruction the towns and villages, have faced Iran natural life and historical evolution with long gaps and dormancies. If we suppose that the antiquity of Iran history and civilization is about three thousand years while Aryan entered this land and established state, we rarely say that there is no nation-state such the residents of this country, that see the aggressive nations invasion and the foreigners interferes in their territory and national affairs and having different governments and states. About 1300 years after Arabs attack till establishment Pahlavi dynasty in fact are the history of attack repetition and tribal governments domination in Iran and continuity the cultural, social, moral and economic structures due to these attacks.. These attacks and invasion caused to spread despoliation and genocides and destroying the dams and irritation irrigation systems, annihilation the productive forces and collapse the social-economic relations, led to numerous gaps and discontinuities in Iran historical evolution. These attacks and also destructions and disturbances due to famines, droughts, uninterrupted wars of captains and local princes and religious faction warfare, had destructive effects on Iran society mind and social consciousness and caused to disassociate national- regional relation and society relation to historical identity dimension (Mirfetros, 1989; 56). As mentioned the Historical Gaps and Political evolutions in the last decades are the main factors that inhibited Iran Political Development; we will study it next.

\section{The effects and Consequences of Iran Historical Gaps}

\subsection{Cultural Segmentation}

Culture is a group of beliefs, believes, values and norms that distinct the behavior of individuals in a society from the other societies (Enayat, 1994, 23). The cultural segmentations can originate in a social system and out of it. In cultural segmentation condition, the entities and governmental procedures do not have the stability and value so, the Historical Development won't come off to participation and competition. As a result, the indifference and social forces political disappointment spreads and decrease the public interest to participate in politics (Bashiriyeh, 2002, 153). According to political cultures segmentations and also their effect on reconstruction and Political Development process by political science theoreticians including limited - confined political culture; the subdominant political culture and participatory political culture(Almond \& Verba,1963) and considering that.subdominant political culture, is the opposite of political development, we should say that Historical Gaps, potentiate the emulation and abandon attribute and disabled the criticism and tract taste and people used emulation and subordination instead of creativeness and attempt. Historical Gaps caused the lack of development the individual and social rights, in the old society of Iran, thus individuals and persons bound themselves to do something or don't and dos and don'ts are not the franchise for individuals. For this reason, the society divides into main two levels subordinate and follower (Enayat,1994, 21, Mokhtari, 1998, 9-14).

\subsection{Identification Partition}

This crisis that originates from individuate the communities and disperses the different social and cultural groups, causes to alienation and human alienation and man from man so on crisis intensity process, individuals become lost identity and worthless agents that they have lost their roles and power and they would be downgraded (Ghavam, 1995, 131-148)..Formation such a phenomenon in Iran is related to the effects of Historical Gaps in the country. There some questions here those are: what level of historical and social destination are people on? how are their dependency to society, their destination and society and their relation to the other people? What responsibilities does the society assign for them?

Government-nation who wants to take step in Political development, first it should provide the identity and 
personality condition for the different group of people and individuals in the society and it should defend its cultural identification, cultural heritage and nature and preserves and secures the national culture against whatever that treat or exceed it. Cultural heritage means the factors that impress us intentionally or unintentionally. The cultural heritage of one nation, demonstrates its unforgettable identification and it is an effective and important factor to self-analysis and self-identify to the others (Varjavand, 1991,5). Preserving the cultural mobility identity depends on its factors mobility, but unfortunately, except elites and educated people, despite the ancient history a long history of their culture and civilization, Iranian don't know much about their territory history and their real identification; the past history isn't common and current among them as a live tradition (Rajaee, 1992,14-23).

\subsection{Political Alienation and Distrust}

Alienation is a kind of imagine, perception or feeling that it is due to disregarding the individual behavior and its determinative role to make results or conversing the truth. About the political systems that recognize the civil law and different kinds of freedom of individuals on the paper, the political alienation reduces or increases easily; because person always compares the laws on the paper with the laws in the real world. More gaps between the written laws and true laws, more political alienation (Mohammadi, 1997, 26-30). M.Zonis in his work The Political Elites in Iran, about their features claims that: "Their main treats are paranoid, insecurity, pessimism, suspicion, detestation and aversion, insincerity, flattery, xenophobia, opportunism, fear, arrogance, megalomania" (Zonis, 2009).

From Political point of view, the most important political alienation factors are deposition, ignoring and inefficacy in decision- makings and policy - makings. In systems that there are no interface entities like guilds, political parties and social organizations, or if there are, they are governmental and normative; individuals mostly feel alienate from political systems (Mohammadi, 1995, 26-30). In Iran society, the most important political alienation factors are deposition, ignoring and inefficacy in decision-makings and policy-makings. As the dictatorial systems of Iran in the past abased prime minister to bondman, therefore, they rarely were interested in politics. Also, as the dictator governments, the autocrats considered they are supranational and their dominion is endowment and charism that it was delegated to them; not only had they believed that they are not responsible to the society demands, but also they expected peasantries to obey them absolutely (Dawson, 1948, 109).

\subsection{Politicization}

One of the most important problems of Iran political under development is the politicization in decision-making process. The dynast family decision makers not only solve the problems with logic and argument analysis, but also they considered their benefits. Even in their speculation, not only they didn't analysis the past, but also they analyzed it based on daily evolutions. The features like being routine, prompt demands, constraints, tensions, competitions and enmities that relate to daily policy are generalized to past and the past was draw in their framework. They ignored that a country that wants to develop it should use the true past traditions at present. But, politicization means that we should glamorize the past identification at the present tense. Charming the daily policy not only there was no development for these country residents, but also it was really effective to preserve the society history (Sariolghalam, 1993; Ghavam, 1993, 12-15).

\subsection{Stereotyping}

History proves this claim that absolute attention to political understanding and political action, are too destructive. Basically, human have an absolute thinking because of fallibility. The absolute thinking and understanding can become dogmatism in speech and action (Sariolghalam, 1997, 18-33). It sounds that stereotyping mentality belongs to societies that are destroyed and damaged by emigrant and interfere nations invasion. Such communities imagine that their indisposition and damage is due to the power of aggressive dominate governor that has power to change the situation the society destination is under his domination. However, sometimes it can be a true imagination, but we can't say that any damage and hurt is from the foreigners and dominant authorities. The analysts and elite perception and presenting examples and clues about conspiracy of dominant authorities and inducing this analysis and believe in the under dominant society mentality, are effective to forming the delusion conspiracy climate. As people who live in such a society are always concern about danger, they relate unpleasant events to the foreigners' conspiracy. Especially it reminds them concepts such as freedom and political independence, the actions and policies of dominant government (Hafeznia, 2003, 196-197). 


\subsection{Extremes in Thinking}

Extremes are ingrained indexes of personality and behavioral Iran society. This problem is always a dominant and determinant principle about Iranian attitude to political events and the peripheral world problems. Here, whatever that challenge Iran political culture and are very important include: 1. Arab neighbors challenging, 2. West civilization challenging. To contrast the historical challenges of Arab neighbors, the educated people in the country try to refining the language and Iranian culture from Arabic language because they believe that the most important and deleterious foreign factor in Iran culture, are the result of "Arabs" actions. Without considering the reality about Iranian and Arabic culture and Iran and Arab culture interaction in Islamic era (Enayat, 1994). Our attitude and treat about West countries were captivation and struggle. Fascination to West, attending struggle the national and religious traditions and struggle to West attending fascination to traditions. Iranian art about thinking and practice, are excess and wastage (extremes) not moderation and golden mean. We haven't found a third solution for it, yet. In words, we are the fan of moderation and in action we are fan of excess and wastage. The main impacts of extremes are ignorance and idiotism in words and in action are aberration and deviance (Dadbeh, 1996, 45; Fuller, 1997,15-18).

\subsection{Considering Freedom}

Freedom is the basic factor of civil society. In concept freedom has ideal and idealistic aspects and probably it never come true; but when a society institutes the positive rationalism and individualism in its culture, it can solve the freedom problem, relatively. A man who doesn't the historical identity and personality, certainly he is free from freedom troubles and has less freedom (Sherosh, 1998, 40-46). About thinking, in this land, the dominant families and the theosophists sometimes abase the wisdom because of religion; argumentation and philosophy are impermissible; obedience and following and allegiance are admissible. About action, freedom started from Iranian missing people during the history of the country specially during the foreign dynasties government, people accepted the freedom, eagerly; because freedom is the human first natural right and its originated thinker human nature force. But Iranian intelligentsia and responsible who were the society critic conscience and the messenger of freedom thought and the government based on wisdom and law and their appearance in Iran contemporary history, as the concept of wisdom, freedom and modernity was faced to struggle, contradiction, ambiguity and negation and it was abject, the accursed social layer and involved in political authority and traditional culture (Mokhtari,1997, 6-7).

\subsection{Lack of Civil Society Formation}

Civil society includes individuals and groups civil law, natural law (vs, sovereignty law), marketing, free economy and cultural areas. Civil society is about social relations and government is about political relations. Civil society is contrast to lawless society. Lawless society, is a society that there is no relation in it and instead of law, the people tastes govern and the changes and up and down of people are controlled by their tastes that wield the society. This society stability and variability depend on tastes stability and variability. As, in civil and regulated societies, individuals define their personality according to law and civilization, they appreciate identity and personality and it can lead to society development (Boshirieh,1996, 329-332).Develop the civil society inhibit the dominant appearance and dictatorship and unidimensional attitude domination. Civil society is a link between the society and the government, thoughts, ideas buffer, it is a link between government and nation, aggregation focus and declaration the society demands and expectations and an agent to transfer the government. The civil society is contrast to mass society because it assimilates the thoughts and ideas of mass; therefor, its realization is necessary to government health and society and nation mobility (Gellner, 1994). Human rescue from despotism, is related to civil society independency, development and enriching it and freedom. Until we establish a civil society, there is no basic entity and structure in a free democratic society (Zonis, 1997, 14-18).

\section{Conclusion}

Aggressive nations invasion during the last centuries to this territory, have caused that government and political authority experienced a fluctuation route during Iran history and inhibit Iran society from the natural development, social and historical evolution. These attack and up and downs had destructive effects on Iran social culture and disassociated the society and historical dimension relation. Any destructive attack was like a sword that disassociated Iran relation and its root and past and this nation condemned to start again. There is no Political Development in different organizations of country if only the national and public appear about Iran society goals. To get development and protection our reverence and identity we should recognize the critical thinking about ourselves and also the world and believe the main values of our culture. This belief can't be acquire with exaggeration about the past history; only criticizing our cultural heritage we can recognize the values that are useful and utilize them as social principal to take step in a new route. 


\section{References}

Abrahamian, E., Ahmad Ashraf, M., \& Katouzian, H. (2008). Inquiries about Conspiracy Theory in Iran. Translation, Mohammad Ebrahim, Fatahi. Tehran: Nay, Publication.

Almond, G., \& Verba, S. (1963). The Civie Culture: Political Attituds and Democaracy in five Nations. Priceton: Priceton university. https://doi.org/10.1515/9781400874569

Bashiriyeh, H. (1996). Political Sociology. Tehran: Nay, Publication.

Curzon George, N. (2012). Persia and the Persian Question (Vol. 2). Publisher: Adegi Graphics LLC. https://doi.org/10.7135/upo9781843318262.038

Dadbeh, A. (1996). West Narration. Economy- Political Information Magazine, 10(3/4).

Dawson, C. (1948). Religion and culture. New York: Meridian Books.

Enayat, H. (1994). We have Ignored the Importance of Recognition the Cultural Values. Economy-Political Information Magazine, 7(11/12).

Fuller, G. (1995). The Center of the Universe: The Geopolitics of Iran. Translation Abass Mokhber. Tehran: Markaz Publication.

Gellner, E. (1994). Conditions of Liberty, Civil Society and its Rivais. New York: Penguin.

Ghavam, A. (1993). Distrust and Political Systems. Healthy Society Magazine, 2(6).

Hafeznia, M. (2003). Political Geography of Iran. Tehran: Samt.

Mirfetros, A. (1989). Consideration about Iran History (4th ed.). France.

Mohammadi, M. (1997). Political Alienation. Development Culture Magazine, 5(22).

Mokhtari, M. (1998). Mistry Speaking to Clear Speaking..Development Culture Magazine, 5(23).

Rajaee, F. (1992). A Review on Iranian Concepts about West. Economy-Political Information Magazine, 5(99-100)

Sariolghalam, M. (1992). Education Requisiteness for Human of Twenty first Century. Tehran: Shahid Beheshti University.

Shorosh, A. K. (1998). Secrecy, Enlightenment and Piety. Tehran: Serat Institute.

Sinzo, A. M. (1997). Duality the Civil Society. Translation Parvize Sedaghat. Development Culture Magazine, $5(22)$.

Varjavand, P. (1991). Preserving the Cultural Identity to away the Capitulation Culture. Economy-Political Information Magazine, 4.

Zibakalam, S. (2000). Conspiracy Delusion. Tehran: Khojasteh.

Zonis, M. (2009). The Psychology Political Elites of Iran. Translation: Parvize Salehi, Solayman Aminzadeh, Zahra Lobadi, Tehran: Chappakhsh.

\section{Copyrights}

Copyright for this article is retained by the author(s), with first publication rights granted to the journal.

This is an open-access article distributed under the terms and conditions of the Creative Commons Attribution license (http://creativecommons.org/licenses/by/4.0/). 